\title{
ACCOUNTING TREATMENT OF PROFIT AS SHARING PROFIT IN MUSYARAKAH TERM AMONG MEMBERS
}

\author{
Muhammad Nurul Hamdi \\ Pondok Pesantren Ar - Raudlatul Hasanah Medan \\ Jl. Letjend Djamin Ginting Km. 11 Simpang Selayang, \\ Medan, Sumatera Utara \\ Email:mhdnurulhamdi@gmail.com
}

Abstrak

Dalam koperasi syariah setiap anggota berkedudukan sebagai mitra yang berserikat dan memiliki hak serta kewajiban yang sama. Kondisi ini diinternalisasikan dalam kebijakan dan segala aktivitas operasi usahanya. Terutama perlakuan laba atau SHU yang akan dibagikan kepada anggota. Hal ini yang ingin dilihat bagaimana Koperasi Serba Usaha Syariah Ahmad Yani mengelola Selisih Hasil Usahanya (SHU).Penelitian ini merupakan penelitian kualitatif deskriptif yang bertujuan untuk memberikan informasi tentang metode perhitungan dan pencatatan akuntansi SHU sebagai bagi hasil dari musyarakah antar anggota di Koperasi Serba Usaha Syariah Ahmad Yani Malang. Alat analisis yang digunakan adalah analisis deskriptif yaitu untuk memberikan gambaran rumusan matematis dan teknis perhitungannya sehingga dapat dibandingkan dengan prinsip syariah dan aturan perkoperasian yang berlaku. Berdasarkan penelitian, diketahui bahwa dari metode perhitungan total SHU dan pendistribusian SHU kepada pos-pos tertentu sudah sesuai dengan UU. No. 25 Tahun 1992 tentang Perkoperasian. Namun untuk metode perhitungan alokasi SHU yang akan dibagikan kepada anggota belum sesuai dengan UU Perkoperasian dan Fatwa DSN-MUI No. 8 tentang Musyarakah di mana SHU yang diterima anggota masih diukur dari aktivitas tabungan saja dan belum mengakomodir kontribusi modal dan aktivitas usaha lainnya. Sementara untuk pencatatan akuntansinya masih perlu pengembangan di beberapa pencatatan.

Kata kunci: koperasi syariah, musyarakah, selisih hasil usaha 
Abstract

Each member of shariah cooperative are same as a partner and having the same rights and obligations. This condition is internalized by policy in all activities and business operations. Especially the profit will be distributed to members. It's meant to see how the cooperatives shariah of ahmad yani manages the difference between the results of their business. The research has descriptived qualitative research that aimed at giving information about the method of calculation and recording as for the result of accounting report of SHU or income in the end of year musyarakah among members in cooperatives shariah of ahmad yani unfortunate. The analysis uses instrument of the descriptive analysis that gives a technical and mathematical formula that the calculation can be compared with the shariah principle and cooperative regulation applicable. Based on the research, it was known that the SHU methods and distribution is in accordance with the rule of Indonesia cooperative No. 25 1992, but accounting methods that related to the profit which will be distributed to members of the cooperative is not suitable with act no. 8 DSN-MUI. The MUI explanation about musyarakah which SHU is about the activities are still measured from savings and not accommodate from the capital and other business activities. Meanwhile, by this condition that cooperative shariah still need developing of the accountance and good recording.

Keywords: sharia cooperative, musyarakah, profit

\section{INTRODUCTION}

Cooperatives as the ideology and institutions are economically based a member of having the esential role in Indonesian economy. As founding father this country who made cooperatives as an economic system. Which it written at Indonesian Base Law (UUD 1945) verse 33 "The Indonesian Economy composed as a mutual effort based on family principle". As follow these command, cooperative which operated by same values. UU No. 25, 1992 about Cooperative has explained that cooperatives based on pancasila and the constitution of 1945 and based on the principle of family spirit. Cooperative also take their role in Indonesian economy significantly. Around 95\% from all entitity in Indonesia are cooperative and another small and medium enterprises providing more job for over than $60 \%$ residents, it is also contributes to GDP almost 50\%. (Depkop, 2013)

Based on Indonesian Law No. 25 verse I which said "The benefit of cooperative is some profit obtainde within an accounting year reduce at a cost of, depreciation and other obligations, including taxes in accounting year concerned." Because cooperatives is a container joint venture, and when allocated to the need for the survival of the activities of a cooperative agency, profit this to be shared to members 
of. The distributed based on agreement in members annual meetings. These principles referenced by cooperative principles which written in Indonesian Law that say "Share of the profits was done fairly comparable to the size of the service effort each member"

The profit distribution concept that has been discussed before have some similiarity with Islamic Contract such as Musyarakah. Where it is the partnership contract between two or more parties to an undertaking in which certain of each party contribute funds by with the agreement that both profits and risks will be covered with in accordance with the agreement (Antonio, 2009:23). Musyarakah was divided into many terms, such as ownership musyarakah and contract musyarakah. Consequently, contract musyarakah is subdivided by Syirkah al'Inan, Syirkah Mufawadhah, Syirkah A'mal, Syirah Wujuh dan Syirkah Mudharabah. The defenition of musyarakah which in another term called by musyarakah mufawadhah, is the contract of cooperation between two or more people, each party provide a portion of the overall funds and participate in work. Losses and gains is borne together. And each parties are eligible for sharing in accordance with the agreement (Antonio, 2009:25).

This concept clearly have in common with the principle of cooperatives. Where any members of voluntarily said its willingness to join cooperative membership with depositing basic saving and compulsory savings. Contribution a member of is certainly not only in just funds, but also give contribution of power, thoughts and often involved in the management of this type of cooperatives. And profit percentage of cooperatives distributed to members of based on their contribution (Buchori, 2012:03).

Author was interacted to see deeply how musyarakah mufawadhah concept is applicated in real cooperative activity at Ahmad Yani Sharia Multi Entreprises Cooperative, Malang. According to Putra (2012) this entity has certain excellence that do not use index interest rates as the best the ratio of the for outcomes good products. Institutions that have been constructed more than a decade is also located at the city center of Malang. Quite strategic if in terms of prospects forward. This institution also considered to have already introduced a prevailing accounting with the performance of is a good enough. But practices the division of the ratio of the in skim musyarakah mufawadhah, researchers have not found research the same thing.

According to that condition, researcher intrested in seeking about profit at Ahmad Yani Sharia Multi Entreprises Cooperative, Malang which concerning in how to calculate and how to manage the profit are appropriate as well as Islamic and Law standard. The chosen formulation of the problem is how calculation, distribution and recording of profit as it's sharing from musyarakah terms at Ahmad Yani Sharia Multi Entreprises Cooperative, Malang is approriate law either in Islamic or Nation Law. (Mandate of DSN MUI No. 08 about Musyarakah Transaction, 
UU No. 25, 1992 about Cooperative, Indonesian Accountancy Standard No. 106 about Musyarakah and Indonesian Accountancy Standard for Cooperative and Small Medium Enterprises Purpose)

\section{THEORITICAL PARADIGMA}

Chaniago in Arifin Sitio and halomoman Tamba argue that cooperative is a sodality consisted of the members or law agency, who give freedom to each member of to go in and out, by cooperating in a family spirit of doing business to heightens welfare daily need of it's members.

Defenition of cooperative that written in Indonesian Law No. 25, 1992 about cooperative is cooperatives are the business consisted of the or body of cooperatives with based on their activities based on the principle of cooperatives, as well as movement public economy based on the principle of family spirit. Of sense it can be formulated important elements cooperatives namely: (1) Cooperative is an entity (2) Cooperative can be built by person or legal entity cooperatives which part of membership in related cooperative (3) Cooperative managed by cooperatives principle base (4) Cooperative managed by family principle base.

Referenced to Buchori (2012:07) common sight of sharia cooperatives is a conversion a conventional one by approaching to Islamic law and followed by the economy that conducted by Rasulullah and his companions. In general, cooperative oprational principle is in order to help welfaring every members with cooperation activity wich help each other in consequent these are not oppose Islamic principle, more over cooperation (ta'awun ala birri) collectively in order to built an independency are part of Islamic value itself. Through these matters, it needed internalization against the process of thinking patterns and the system of management products and Law imposed to be in accordance with sharia.

Regarding to UU No. 25, 1992 Section 1 and 2 "Profit in cooperative term is earnings that obtained one period of economic activity reduced at a cost of, depreciation, and other obligations including taxes in financial year concerned".

The accounting method with presenting information on income and loads business and load of cooperative during a given period. Calculations of the outcome of business provides the results of the end of which is called by profit in cooperative terms. The profit that obtained includes businesses with members and profit or loss dirty with non members. The term calculations of the outcome of have used remember the benefit of the activities of a cooperative not only measured from the rest of businesses or profit, but much depends on the benefits for members (Rudianto, 2010:196).

Referenced to Decision of Minister of Cooperative and Small Medium Enterprises No. 19/KEP/Meneg/III/2000 about Institutional Guideliness and The Activities of Cooperative, distribution of profit was managed as these rule, are: 
Profit derived from business held by members of, was distributed for reserve cooperatives, members in proportion to services each, the funds, funds civil servant and employees, education funding cooperatives, social funds, local development funds for work.

Profit cannot be divided up, because the division of profit in cooperative has been constrained by stipulation set out in the articles of association approved by a member of the very first time the establishment of cooperative or has changed and implemented as the basis the determination of the division of profit. In general members meetings decided shu financial year concerned stay in the bank accounts of savings each member, was detained for used as fertilizing capital. This is called with reserve cooperatives

The definiton of musharakah, lexically syarikah means ikhtilath (intermixture) , which intermixturing one property by property to another, so he could not be distinguished between them. Next Jumhur Ulama have said syarikah to label one transaction, even though there were no intermixture two parts, due to the occurrence of a transaction is so we mingling (Wiroso, 2011:393).

\section{RESEARCH METHODOLOGY}

This type of research that using is qualitative research. This method is used to see more in the calculation and management of the SHU as well as for compliance with the law and generally standards. While the approach using descriptive analysis because of the problems that is being researched is a problem that is going on. This research was conducted in a Sharia Cooperative Ahmad Yani Malang. Located in Jl. Kahuripan No. 12, neighbor of Ahmad Yani Mosque Malang.

Types of data used in this research is the primary data and secondary data. Where primary data obtained from observation and interviews with the SOP. While secondary data obtained from the other participant that has been processed into a form and become relevant to this research.

Method of data collection by recording the results of documentation and interviews. This research uses qualitative descriptive data analysis methods that the process of organizing is by sorting data and sort out the data into manageable units.

\section{RESEARCH RESULTS}

\section{The Methods Of Calculation And Distribution of SHU in Sharia Cooperative Ahmad Yani Malang}

From the observations and interviews with Mrs. Ika, Finance Manager of Sharia Cooperative Ahmad Yani then got information that the policy management of SHU in these cooperatives contained in the form of a SOP (Standard Operating 
Procedure). Where this SOP contains instructions regarding the calculation of the technical implementation.

For calculate the total acquisition of SHU as a whole in one period based on SOP, KSU Sharia Ahmad Yani set them up with a mathematical formula:

$$
\text { SHU }=\text { TR }- \text { TC }
$$

Gambar 1. Mathematical Model in Calculating Total Profit in a Period of Time at Ahmad Yani Sharia Cooperative

Source: Ika, Based on Calculating Profit Procedure

From the results of interviews with Ika, the explanation of the above formula as:

"SHU is net income as other profitentitas. Furthermore she explains TR (Total Revenue) is the accumulation of the whole income of the cooperative in a year then collected from any products and services at Sharia Cooperative Ahmad Yani, and TC (Total Cost) is the accumulation of total costs, expense, liabilities and cooperative tax issued within one year of the same period."

Once known the amount of SHU earned for one year, she also said that based on the standard that owned by KSU Sharia Ahmad Yani, the next step is distributing the accumulation of SHU to the related posts. The following is the allocation of posts at KSU SHU Sharia Ahmad Yani with the percentage are:

Tabel 1. Alocation Percentage of Profit at Ahmad Yani Sharia Cooperative

\begin{tabular}{clc}
\hline No & \multicolumn{1}{c}{ Sasaran } & Prosentase \\
\hline 1 & Cadangan Koperasi & $25 \%$ \\
2 & Modal Koperasi & $20 \%$ \\
3 & Dana Anggota dan Anggota Luar Biasa & $20 \%$ \\
4 & Dana Pegawai / Karyawan & $10 \%$ \\
5 & Dana Pengurus & $10 \%$ \\
6 & Dana Pendidikan & $5 \%$ \\
7 & Dana Sosial / Baitul Maal & $10 \%$ \\
\hline
\end{tabular}

Source: Ika, Based on Calculating Profit Procedure

So, when SHU earned by Cooperative Sharia Business Department Ahmad Yani Malang in $2014 \mathrm{Rp} 210.000 .000$,-then the distributing to the cooperation deposit of Rp 52.500.000, and for cooperative capital to Rp 42 million, to members and extraordinary members fund of Rp 42 million,to employee funds Rp 21.000.000, superintendent fund Rp-21.000.000,to education fund Rp. 10.500.000, and for the Social Fund Rp 21.000.000 the allocation can figured on the table: 
Tabel 2. Simulation the Number Of Allocation Profit in Ahmad Yani Sharia Cooperative

\begin{tabular}{llc}
\hline No & \multicolumn{1}{c}{ Sasaran } & Prosentase \\
\hline 1 & Cadangan Koperasi & $R p ~ 52.500 .000,-$ \\
2 & Modal Koperasi & $R p ~ 42.000 .000,-$ \\
3 & Dana Anggota dan Anggota Luar Biasa & $R p ~ 42.000 .000,-$ \\
4 & Dana Pegawai / Karyawan & $R p 21.000 .000,-$ \\
5 & Dana Pengurus & $R p 21.000 .000,-$ \\
6 & Dana Pendidikan & $R p ~ 10.500 .000,-$ \\
7 & Dana So sial / Baitul Maal & $R p 21.000 .000,-$ \\
\hline
\end{tabular}

Source: Ika, Based on Calculating Profit Procedure

Simulation on top instead of in the actual amount due to the institution's policy at the time of the research underway to prohibit access to the actual financial data. But this is a simulated image of the actual calculations.

\section{Calculation Method Allocation for SHU which will be Distributed to Mem- bers in The Cooperative Sharia Ahmad Yani Malang}

Mrs. Ika said that the members were one of those who get a portion of the SHU Sharia Business Cooperative Ahmad Yani. Magnitudes received by members is $20 \%$ of the total acquisition of SHU during the accounting period. But to count how many SHU to be gained by each Member, KSU Sharia Ahmad Yani formulating model count with a mathematical formula. The formula can figured by:

$$
\left(\frac{\text { Saldo Rata - Rata Perbulan }}{\text { Total Saldo Rata - Rata Perbulan }} \times \text { SHU }\right) \times \text { Nis bah Bagi Hasil }
$$

Gambar 2. The Calculation Formula of total Profit for a Periode in Ahmad Yani Sharia Cooperative

Source: Ika, Based on Calculating Profit Procedure

To find out the calculations technical, then make a simulation by Mrs. Ika with the calculation that using in KSU Sharia Ahmad Yani. The calculations can figure by:With a total of SHU Rp 210.000 .000 and ratio of 3\% and assumed the information that received from the savings card of Ahmad is as follows. 
Tabel 3. Simulations of Member Saving Card "X" in 2014 At Ahmad Yani Sharia Cooperative

\begin{tabular}{|c|c|c|c|}
\hline Bulan & Tanggal & Setoran & $\begin{array}{c}\text { Total Saldo } \\
\text { Perbulan }\end{array}$ \\
\hline Januari & 15 & Rp 20.000,- & Rp 2.000.000,- \\
\hline Februari & 15 & Rp 35.000,- & Rp 1.200.000,- \\
\hline Maret & 13 & Rp 20.000,- & Rp 1.350.000,- \\
\hline April & 26 & Rp 15.000,- & Rp 1.450.000,- \\
\hline Mei & 28 & Rp 50.000,- & Rp 1.750.000,- \\
\hline Juni & 10 & Rp 25.000,- & Rp 1.200.000,- \\
\hline Juli & 19 & Rp 30.000,- & Rp 980.000,- \\
\hline Agu stus & 6 & Rp 15.000,- & Rp 650.000,- \\
\hline September & 9 & Rp 20.000,- & $\operatorname{Rp} 780.000,-$ \\
\hline Oktober & 31 & Rp 30.000,- & Rp 850.000,- \\
\hline Nopember & 28 & Rp 50.000,- & Rp 900.000,- \\
\hline Desember & 15 & Rp 50.000,- & Rp 1.300.000,-- \\
\hline \multirow{2}{*}{\multicolumn{2}{|c|}{$\begin{array}{c}\text { Total } \\
\text { Rata-Rata }\end{array}$}} & Rp 360.000,- & Rp 14.410.000,- \\
\hline & & Rp 30.000,- & Rp 1.200.833,- \\
\hline
\end{tabular}

Sumber: Ika, berdasarkan SOP perhitungan SHU

Bagi Hasil dari Tabungan $=\left(\frac{30.000}{1.200 .000} \times 42.000 .000\right) \times 3 \%$

$$
=\operatorname{Rp} 31.478
$$

\section{The Method of Accounting Documentation}

As an entity, Sharia Cooperative Ahmad Yani also noted and reported the results of the operational activity. Based on the results of observation and interviews with Ika, financial managers obtained technical information of journaling on a documentation of SHU in KSU Sharia Ahmad Yani. The following method of documentation transactions related to SHU on Sharia Cooperative Ahmad Yani.

\begin{tabular}{clcr}
\hline Tanggal & \multicolumn{1}{c}{ Akun } & Debet & Kredit \\
\hline 31 Desember & $\begin{array}{l}\text { Sisa Hasil Usaha } \\
\text { Kas }\end{array}$ & Xxx & Xxx \\
\hline
\end{tabular}

Gambar 3. The Record Journal Of Profit at Ahmad Yani Sharia Cooperative

Source: Ika, Based on Calculating Profit Procedure

\section{ANALYSIS OF RESEARCH RESULT}

Sharia Cooperative Ahmad Yani better known as BMT Ahmad Yani basically use the legal basis and foundation of cooperative operations in general. This institution also based by activities on the Quran and the Hadith as a consequence of sharia principles. The base is then internalized into all aspects of the activity. This then 
becomes added value of microfinance institutions and others. Where this institution in addition to accommodate family values and mutual as cooperatives in General, and also uses the principle of Islam that we as Muslims believe as a perfect system and brought the affairs as well as rahmatanlil' alamin.

The diffenceprinciple of the institutional seem from the position of the member. In this cooperative, members of the cooperative serves as the owner also simultaneously acts as a cooperative service users (principle of identity). Position as shown by the owner's founder, financier, manager and supervisor/controller of the company. Whereas the position of a member as a customer or user of the service can be seen from the activities of members that also uses the services of the cooperative in the economy activity (Pratomo, 2009:51). Both this position to its partial or not is one of unity, so that members with the rules and conditions that apply are entitled to be involved in deciding policies in the cooperative. So that all the members be involved in promoting and enhancing the benefits of cooperation are also entitled to a portion of the profits that accrue to the cooperative.

The profit to describe the difference between earnings received during a certain period and the sacrifice incurred to earn income in the cooperative is not knowing with the profit, but called with business results (SHU). So also with the Sharia Cooperative Ahmad Yani who used SHU. This the policy regarding the SHU in Sharia Cooperative Ahmad Yani.

From the results of interviews with Ika, the explanation of the above formula as: "SHU is net income as other profitentitas. Furthermore she explains TR (Total Revenue) is the accumulation of the whole income of the cooperative in a year then collected from any products and services at Shariah Cooperative Ahmad Yani, and TC (Total Cost) is the accumulation of total costs, expense, liabilities and cooperative tax issued within one year of the same period."

From the results of interviews with Ika, the explanation of the above formula as: "SHU is net income as other profitentitas. Furthermore she explains TR (Total Revenue) is the accumulation of the whole income of the cooperative in a year then collected from any products and services at Shariah Cooperative Ahmad Yani, and TC (Total Cost) is the accumulation of total costs, expense, liabilities and cooperative tax issued within one year of the same period."

\section{DISCUSSION OF RESEARCH RESULT}

Cooperative Sharia of Ahmad Yani or well-known as BMT Ahmad Yani actually using the base of law and operational of cooperative. This institute also rest its activity on al Quran and Hadist as consequence of sharia principle which is used. The base then internalized into all of aspect of its activity.

The added value from the other micro finance institute beside accommodate the values of family atmosphere and mutual cooperation as cooperative in general, 
it also uses islamic principle which is believed by us as the moeslem, that it is a perfect system and bring the maslahat and rahmatan lil 'alamin.

The difference of institutional principle appears from the position of member. In cooperative, beside as the owner, the member also has a role as the user of cooprative's service (identity principle). Position as owner showed by their role as the founder, capitalist, processor and supervisor/manager of the corporation. However the position of member as the customer and the user of service can be seen from the member activities who also use cooperative's service on their economic activity (Pratomo, 2009:51). Both of the position have non partial characteristic or include of one unit. So that member with the rule and certainty which occur have right to be involved on the process of making policy in cooperative. So that all of members involved on the advance and raising of the profit of cooperative also have right to get some of the profit which is gotten from that cooperative.

The advantage toshow thedifferencebetweenthe income receivedduring a certain periodandsacrificesincurred toearn incomein the cooperativedoes notrecognize the termprofits, butcalled Selisih Hasil Usaha (SHU). Likewise withCooperativeSharia ofAhmadYaniwhich use the term SHU. The followingpolicies regardingSHUinCooperativeSharia of AhmadYani.

\section{The Discussion of Accounting Method and Distribution of SHU in Cooperative Sharia of Ahmad Yani.}

\section{Accouting Method of SHU}

To analyze the accounting methode of SHU used by Cooperative Sharia of Ahmad Yani, an analysis tool usedisthe Law. No.25 of 1992regarding cooperatives. Where thearticlethat discusses theSHUis locatedinchapter45.The contentsinclude: (a) SHU cooperativeis a cooperative income earned in the financial year minus costs, depreciation, and other liabilities, including taxes in the fiscal year concerned. (b) SHU after deducting the reserve fund, distributed to members in proportion to the services of the work done by each member of the cooperative, and used for other purposes in accordance with the decision of the co-operative Meeting of Members. (c) The amount of additions to reserves set out in the Meeting of Members

SHU overallac quisition calculations in cooperatives in general should clear lyrefer to the points (a). See the formula that is used by the Multipurpose Cooperative Sharia Ahmad Yani as in the previous section that assumes the entire income for a year the accounting books with the term TR with subtracted from $\mathrm{T}$ Corall of the costs incurred during the same year, the formulation is considered appropriate and are in accordance with the applicable rules. 


\section{SHU Distribution}

In general, SHU cooperative obtained during an accounting period must be distributed to the members. However, if done so then going concern cooperative will be threatened. Therefore, SHUat least should be allocated to some of the posts that have been budgeted in the statutes and by laws of the cooperative. But at least, based on points (b) the description of the grains laws No.25 of 1992 regarding cooperatives and more specifically discuss the SHU as described above, at least SHU should be allocated to the Reserve Fund, the Fund Member and Member Education Fund.

However, based on the Decreeof the Ministerof Cooperatives and UKM No. 19/KEP/Meneg/III/2000 on Guidelines for Institutional and Cooperative Enterprises, the division of the cooperatives operation profit SHU must be distributed to the following posts: (a) Reserve (b) Member's fund (c) Board's fund (d) Employees' fund (e)Educationfund (f) Social fund (g) WorkRegional Development Fund.

As far as resear chers have observed, for the amount of the percentage of each item above is not determined by the government in this case the Ministry of Cooperative and UKM, so that these quantities can be discussed an dagreed upon by the members as a basis for cooperative activities in each.

Similarly, Cooperative Sharia Ahmad Yani who have somepost-its to the allocation SHU. Dataon exposure, has been described SHU allocation of posts with in a specific period at Cooperative Sharia of Ahmad Yani complete with massive percentage.

When referring to the basic rules as stated in the Act and the Decree above, the allocation made by the Cooperative sharia of Ahmad Yani is right. Only, for allocation Work Regional Development, as stated in the last postby Decree No.19/ KEP/Meneg/III/2000 on Guide lines for Institutional and Cooperative Enterprises does not exist in Cooperative Sharia of Ahmad Yani. The researchers then confirmedit, and according to Ika, Cooperative Sharia of Ahmad Yani does not separately provide the allocation and considers the allocation of social fundsal ready accommodate to these allocations.

If seen from the magnitude of the percentage, the largest portion back to the institution. The institutional portionis intended among other thing store serves and capital of cooperatives. Postal reserve fund is to be used as cover loss or other bad things that happen in the future, in addition to there servecan also be used for business development. While the cooperative capitalis here used as a tool tomainta in aco-operative cash flow so that the flow of funds in Cooperative Sharia of Ahmad Yanican run up. Remembering the core of Cooperative Sharia of Ahmad Yani is asavings and loan services which will have a significant effect on the activity of the institution if the cash flowis not stable.

Other dominant enough portionis the portion reserved for members. As also described in the previous section, there are no specificrules on this percentage, 
that percent age was handed over to members of a cooperative agreement in the Meeting of Members. After wards included in the By laws of the Cooperative or in other institution alrules and standards.

The divisionis based SHU to members because the members also serves as the owner is entitled to benefit from the entity that owns. However, because of the cooperative nature of collective ownership, so that the calculation method become surgent to have that distribution to each member in accordance with the principles of cooperatives and Islamic principles.

\section{Accounting Method of SHU which Shared to Members}

To analyze the accounting method of SHU allocated to members using the two basic laws. The first use of the basic DSN-MUI Fatwa No. 08 of 2000 on Musyarakah Agreement, and the second use of the Law No. 25 of 1992 concerning Cooperatives.

If observed from certainty about profit in the contract musyarakah of DSNMUI Fatwa No.08, 2000 is as follows: (a) Profit should be quantified clearly to avoid differences and disputes at the time of allocation of profit or termination Musyarakah (b) Each partner profits should be distributed proportionally on the basis of all benefits and no amount specified in the initial adopted by forapartner (c) A partner may propose that if the gain exceeds a certain amount, the excess or the percentage given to him (d) Benefit-sharing systems should beset out clearly in the contract Further more, in terms of allocation offunds of SHU provisions under Law No.25 of 1992 concerning Cooperative sex plained as follows.

"Business Profits net ofreserve funds, distributed tomembers in proportion to the services of the work done by each member of the cooperative, and used for other purposes in accordance with the decision of the cooperative Meeting of Members.",

The rudiments above is not elaborate on detail about the mechanism the distribution of profit and it will be distributed to every members. While Rudianto said (2010:198) Because of members in cooperatives stand as the owner and users, so the profit distribution should have to go of both position. Therefore, the number of received by each member measured based on services capital in the form of basic saving and compulsory savings of with service effort from savings and loan transactions. It is the same with the rules at over in general stressed the principle of justice well-proportioned and comprehensive to distributed profit to every members. Because the partnership will not run with better if this principle not be enforced clearly. Allah said:

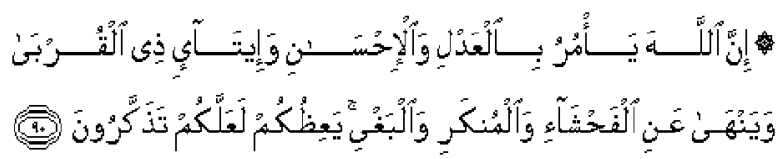


"Allah commands you to justice and kindness, given your relatives, and he forbids indecency, and evil and rebellion.." (QS. An Nahl: 90)

Justice in the context of the distribution of profit is certainly suit of one of the basic principle of 7 principle cooperatives requiring profit be distributed in accordance with the contribution capital and business of each members. So that the distribution will be well-proportioned and partnership in cooperatives can unsullied.

Regarding to the profit calculation in mathematical formulation owned by general cooperatives Sharia Ahmad Yani city compared with the provisions of poor as described above it can be taken the conclusion that methods used have not been in accordance. This conclusion in terms of formulation that is, where calculation shu a member of based on just one activity. That is saving deposited to cooperatives. While the cooperatives should be given profit calculation based on capital and other economic activity.

According to these conclusion, then this research recommend the model that can be applied in Ahmad Yani Sharia Cooperative in distributing their profit to their members. Perscentage that will be used in this methode become optional which can discussed more as well as by every members to make some agreements and managers itself.

The percentage of each indicator separated into some situation which regarding to their main business, saving and loan. After multiplying by percentage which will distributed to every members from whole profit that earn by cooperative in a period of accountancy. Where percentage has been $20 \%$. Furthermore, capital contribution obtained 30\%, saving : $30 \%$ and loan contribution $40 \%$. These model will be explained by mathematical approaching:

Formulation used to calculate services a member of the contribution of services capital from each member

Members Capital's Contribution $=\frac{\text { Members Capital } x \text { Total Capital Contribution }}{\text { Total Capital }}$

Formulation used to calculate services a member of the contribution of services economic activities (Savings, loans and another activity that have been agreed by the policies of the management and members meetings) from each member.

Member savings contribution $=\frac{\text { Total Member Saving } \mathrm{x} \text { Savings Contributi on }}{\text { Total Saving for All Members }}$

Loan contribution $=\frac{\text { Loan Avaerage }}{\text { Total Average Loan }} \times$ Loans Contribution

For instance, if Ahmad Yani Sharia Cooperative's members are 450 persons. Each member should pay principal savings Rp 100,000,- and compulsary savings 
Rp 25.000,- per month. At the end of December 2014, whole principal savings reach Rp. 500,000,000,- which total profit Rp. 210,000,000 and the alocation of that profit wich will be distributed to members is $\mathrm{Rp} 42.000 .000,-$.

\section{CONCLUSION}

Calculating method and profit distribution has been appropriate to Fatwa DSNMUI No. 08 About Musyarakah Transaction dan UU No. 25. While calculating method of distributed profit has not appropriate yet by the same guiding. Where the profit received a member of are still measured from savings activity only, and have not accommodate contribution capital and other business activity. A method of recording an accounting relating to transactions shu still not according to the theory accounting cooperatives in virtue of PSAK 106 about Musyarakah and SAK ETAP

\section{DAFTAR PUSTAKA}

Al Quran

Hadist

Antonio, M. Syafi'i. 2001. Bank Syari'ah Dari Teori ke Praktek. Jakarta: PT Gema Insani Press.

Buchori, Nur, S. 2012. Koperasi Syariah, Teori ke Praktik. Banten: Pustaka Aufa Medika Press.

Bungin, B. 2006. Metodologi Penelitian Kuantitatif: Komunikasi, Ekonomi dan Kebijakan Publik serta Ilmu-ilmu Sosial Lainnya, ed.I cet.2. Jakarta: Kencana.

Fatwa Dewan Syari' ah Nasional Majelis Ulama Indonesia (DSN MUI) No. 08 Tentang Akad Musyarakah Tahun 2000.

Jafar, T.D.F. 2012. Analisis Pendistribusian Laba dalam Akuntansi Syariah untuk Mencapai Prinsip Keadilan (Studi Kasus Pada PT. Bank Muamalat Indonesia TBK.) Skripsi: FE - Unhas.

Pernyataan Standar Akuntansi Keuangan (PSAK) No. 106 Tentang Transaksi Musyarakah Tahun 2007.

Pratomo, S. 2009. Koperasi Dalam Pembagunan Indonesia. Yogyakarta: Al-Qisthi Press.

Putra, B.P. 2012. Analisis Penetapan Tingkat Marjin Akad Pembiayaan Murabahah: Studi Kasus pada Baitul Maal wa Tamwil Ahmad Yani Malang. Jurnal Ilmiah FEB - UB.

Rudianto. 2010. Akuntansi Koperasi. Jakarta: Penerbit Erlangga.

Sabarguna. 2008. Analisis Data Pada Penelitian Kualitatif. Jakarta: UI Press.

Selesa, E. 2008. Analisis Kebijakan Pemerintah tentang Koperasi Syariah Ditinjau dari Perspektif Islam. Skripsi: FSH-UIN Syahid Jakarta.

Undang-Undang No. 25 Tahun 1992 Tentang Perkoperasian.

Wiroso. 2011. Akuntansi Syariah. Jakarta: IAI-Press. 